\title{
PERBANDINGAN SISTEM BAGI HASIL DAN BUNGA \\ SERTA IMPLEMENTASI PADA BIAYA
}

\author{
Amiludin \\ Mahasiswa Program Pascasarjana \\ Universitas Islam Negeri Sunan Gunung Djati Bandung \\ amilDN30@gmail.com
}

\begin{abstract}
ABSTRAK
Perilaku produsen dipengaruhi oleh dua motif, yakni maksimalisasi profit dan minimalisasi biaya, untuk mencapai tujuan tersebut dibutuhkan suatu cara yang paling efektif dan efisien dengan memilih jenis sumber modal atau biaya. Perusahaan dalam pandangan Islam dapat memilih sumber modal yang tepat untuk mengoptimalkan output (produk) perusahaan, seperti qard, syirkah, mudharabah. Terdapat empat aspek dalam perdandingan sestem bagi hasil dan biaya: (1) biaya bunga yang harus dibayarkan produsen bersifat tetap, sehingga termasuk pada biaya (fixed cost), sedangkan dalam sistem bagi hasil akan mempengaruhi pada total revenue, (2) sistem profit sharing, ketika rugi kurva total revenue digambarkan dengan mulut buaya bawah, sedangkan ketika untung digambarkan dengan mulut buaya atas, berbeda halnya dengan sistem revenue sharing, kurva total revenue bergeser mendekati garis horizontal, (3) produksi dalam jumlah yang sama (Q), biaya total sistem bagi hasil selalu lebih kecil dibandingkan sitem bunga, dikarenakan bunga menjadi beban bagi produsen, karena biaya tetap naik, maka akan meningkatkan biaya total, (4) memaksimalkan produksi tanpa ada perubahan biaya, dengan menggunakan kurva TC yaitu membandingkan biaya total sistem bunga dengan sistem bagi hasil, dari hasil analisis menunjukkan biaya yang sama, jumlah produksi yang dihasilkan sistem bagi hasil lebih efisien dibandingkan sistem bunga.
\end{abstract}

Kata Kunci: Sistem Bagi Hasil, Sistem Bunga, Biaya Produksi 


\section{PENDAHULUAN}

Al-quran dan Al-hadist merupakan pedoman utama bagi umat manusia terutama muslim yang didalamnya terdapat banyak perintah untuk bekerja. Manusia diberikan kebebasan untuk bekerja apa saja, sepanjang pekerjaan tersebut tidak bertentangan dengan syariat Islam. Ia dapat melakukan aktivitas produksi, dimisalkan kegiatan perkebunan, pertanian, peternakan, pengolahan makanan dan minuman, dan lain sebagainya. Ia pula dapat melakukan aktivitas distribusi, seperti perdagangan, logististik, dan lain sebagainya bahkan dalam melakukan aktivitas jasa, dimisalkan jasa transportasi, kesehatan, dan lain sejenisnya.

Hal yang harus diperhatikan dalam melakukan suatu kegiatan usaha, sejatinya diperlukan suatu modal yang disesuaikan pada sekala usaha, bahkan sekecil apa pun jenis usaha yang sedang dan akan dilakukan, tentunya selalu membutuhkan modal (capital). Modal dapat diperoleh dari simpanan pribadi (modal internal) maupun diperoleh dari luar (eksternal), seperti halnya modal

\footnotetext{
${ }^{1}$ Pemberian harta kepada orang lain yang dapat ditagih atau diminta kembali atau dengan kata lain meminjamkan tanpa mengharakan imbalan, definisi lain qard dikategorikan suatu akad saling membantu dan bukan transaksi komersial, Ahmad as-Syarbasyi dalam Syafii Antonio, 313.

${ }^{2}$ Akad kerjasama antara kedua belah pihak atau lebih untuk suatu usaha dimana masing-masing pihak
}

hasil pinjaman dan sejenisnya. Modal tersebut tentu diperuntukan untuk keperluan biaya oprasional dalam kegiatan usaha dan bisnis.

Perilaku produsen ada dua, maksimalisasi profit dan minimalisasi biaya. Perilaku produsen untuk mencapai tujuan tersebut membutuhkan suatu cara yang paling efektif dan efisien dengan memilih jenis sumber modal (capital). Perusahaan dapat memilih sumber modal apa yang tepat untuk mengoptimalkan output (produk), seperti qard ${ }^{1}$, syirkah², mudharabah ${ }^{3}$, ataupun menerapkan prinsip perolehan modal secara konvensional dalam artian meminjam uang ke bank yang menerapkan sistem bunga.

Sumber modal yang berbeda dapat memberikan efek yang berbeda terhadap output. Oleh karena itu, perusahaan melakukan analisis biaya sebagai salah satu metode untuk mengestimasi seberapa besar profit yang akan diperoleh dengan biaya tertentu. Maka, dalam tulisan ini, akan dibahas bagaimana perbandingan ketika sebuah perusahaan menggunakan sistem

memberikan kontribusi yang sama dengan kesepakatan bahwa keuntungan dan resiko akan ditanggung bersama sesuai dengan kesepakatan, Bisayatul Mujtahid II, dalam syafii Antonio, 90.

${ }^{3} \mathrm{Akad}$ kerjasama antara dua pihak atau lebih dimana pihak pertama bertindak sebagai shahibul maal yang menyediakan modal $100 \%$, sedangkan pihak lainnya sebagai pengelola, M. Safii Antonio, 95. 
bunga atau bagi hasil sebagai tambahan modal (capital) untuk biaya produksi.

\section{PEMBAHASAN}

\section{Bagi Hasil}

Konsep bagi hasil (profit sharing) dapat diartikan sebagai konsep pembagian keuntungan. ${ }^{4}$ Menurut Muhamad dalam Ridwan mengatakan bagi hasil adalah suatu konsep distribusi beberapa bagian laba (keuntungan) atau pendapatan berupa laba akhir, bonus, dan lain sebagainya pada suatu perusahaan. Bagi hasil merupakan sistem pembagian hasil usaha atau deviden (keuntungan) antara shahibull mal dan mudharib. ${ }^{5}$ Sistem bagi hasil ini umumnya diterapkan pada lembaga keuangan Islam yaitu pada produk muayarakah dan mudharabah. Sistem bagi hasil merupakan karakteristik dan landasan dasar bagi operasional perbankan syariah, dengan menjadikan bank syariah sebagai mitra (panther) bagi nasabah atau pengusaha yang meminjam dana. ${ }^{6}$

Implementasi sistem bagi hasil pada lembaga keuangan syariah, sebagai contoh penerapan pada akad mudharabah yang

\footnotetext{
${ }^{4}$ Muhamad, "Sistem dan Prosedur Operasional Bank Syariah", (Yogyakarta: UII Press, 2005), 105.

${ }^{5}$ Muhamad dan Dwi S., "Akuntansi Perbankan Syariah", (Yogyakarta: Trust Media, 2009), 10.
}

mengharuskan membuat kesepakatan dengan mudharib (pengelola dana) mengenai pembagian keuntungan (presentase bagi hasil) yang ditentukan dalam akad.7 Presentase bagi hasil tersebut dipengaruhi oleh beberapa faktor: kesepakatan dari pengelola dana (mudharib), kemungkinan keuntungan yang akan diperoleh, respon pasar, kemampuan manajemen perusahaan serta masa berlakunya kontrak. Apabila kontrak mudharabah tidak memperoleh keuntungan, maka mudharib tidak memperoleh imbalan atau upah atas pekerjaannya. Jika terjadi kerugian, shahibul maal yang menanggung atas kerugian tersebut selagi kerugian tersebut tidak diakibatkan oleh kelalaian mudharib (pengelola dana) dan tidak menyelewengkan atau terjadi kesalahan dalam manajemen dana. Namun jika hal itu yang sebaliknya, maka mudhariblah yang berhak menanggung atas kerugian tersebut. ${ }^{8}$

\section{Nisbah}

Kata nisbah dapat didefinisikan sebagai proporsi pembagian hasil. Nisbah ini ditetapkan dalam akad. Sebelum akad disetujui dengan bukti tandatangan oleh

${ }^{6} / \mathrm{bid}$, h. 97.

${ }^{7}$ A. Saeed, "Bank Islam dan Bunga", (Yogyakarta: Pustaka Pelajar, 2004), 104.

${ }^{8}$ Ibid, h. 105. 
kedua belah pihak dapat mengajukan atau melakukan penawaran sampai pada kata kesepakatan. Berbeda halnya dengan sistem bunga, nasabah berada pada posisi pasif dan senantiasa menerima ketentuan yang berlaku, dikarenakan pada sistem bunga menjadi kewenangan pihak bank sepenuhnya. Nisbah bagi hasil merupakan suatu faktor penting dalam menentukan bagi hasil pada lembaga keuangan Syariah disebabkan nisbah merupakan aspek yang disepakati secara bersama diantara kedua belah pihak yang melakukan transaksi bisnis. ${ }^{9}$

Nisbah adalah sebagai pembagian keuntungan yang terbagi dalam bentuk persentase antara shahibul maal (pemilik modal) dan mudharib (pengelola modal). Kesepakatan nisbah ini selanjutnya dituangkan dalam akad bersama baik secara lisan maupun tulisan, serta atas dasar kehendak atau kerelaan bersama antara bank dan nasabah (antarodim mingkum).

\section{Perbedaan Bagi Hasil dan Bunga}

Islam sangat menganjurkan para penganutnya untuk melakukan praktik bagi hasil dalam kegiatan muamalahnya dan mengharamkan praktik bunga (riba). Praktik bagi hasil dan riba memiliki persamaan, yaitu memberikan profit bagi pemilik modal, akan tetapi terdapat perbedaan signifikan antara lain: (1) proses penentuan besaran bunga dibuat pada waktu akad/kesepakatan yang selalu diasumsikan harus dalam keadaan untung, sedangkan pada penentuan besaran rasio/nisbah (pembagian keuntungan) sistem bagi hasil dibuat pada waktu akad dengan berpedomankan berbagai kemungkinan yang akan terjadi (bisa untung maupun rugi), (2) persentase besaran bunga didasarkan pada jumlah uang atau modal yang dipinjamkan, sedangkan persentase besaran rasio bagi hasil didasarkan pada jumlah keuntungan yang diperoleh, (3) pada sistem pembayaran bunga sifatnya tetap sesuai dengan apa yang telah disepakati diawal, juga tanpa mempertimbangkan apakah usaha yang dijalankan oleh pihak nasabah sedang mengalami keuntungan atau kerugian, berbeda halnya pada sistem bagi hasil dimana pembayaran tergantung pada keuntungan usaha yang sedang dijalani, dengan kata lain bila perusahaan yang dijalankan mengalami defisit, maka kerugian tersebut akan ditanggung bersama oleh kedua belah pihak berdasarkan pada kesepakatan bersama, (4) pembayaran bunga tidak mengalami elastisitas dalam

${ }^{9}$ Muhamad, "Sistem dan Prosedur Operasional Bank Syariah", 47. 
artian jumlah pembayaran bunga tidak akan mengalami peningkatan juga tidak mengalami penurunan sekalipun dalam kondisi keuntungan atau pendapatan perusahaan mengalami peningkatan yang cukup signifikan, akan tetapi berbeda dengan sistem bagi hasil dimana persentase pembagian laba/keuntungan dalam bagi hasil akan mengalami elastisitas yakni bisa meningkat juga bisa menurun sesuai dengan peningkatan jumlah pendapatan ataupun penurunan pendapatan pada usaha yang sedang dijalani, (5) dari segi eksistensi sistem bunga sangat diragukan (kalau tidak dikecam) oleh berbagai agama termasuk agama Islam, berbeda halnya pada sistem bagi hasil yang tidak diragukan lagi akan keabsahannya karena dianggap fair (adil).

\section{Biaya}

Biaya adalah segala sesuatu yang korbankan dengan tujuan hanya untuk memperoleh suatu hal yang lebih dari biaya yang dikorbankan, biaya tersebut bisa berwujud uang dan bisa juga tidak berwujud. Biaya erat kaitannya dengan kegiatan produksi. Biaya produksi merupakan berbagai bentuk pengeluaran yang dilakukan oleh perusahaan dengan tujuan untuk memperoleh

\footnotetext{
${ }^{10}$ Bachrudin S. dkk, "Ekonomi Mikro, (Yogyakarta: Budi Utama”, 2019), 103.
}

berbagai faktor produksi serta bahan-bahan mentah yang akan digunakan dalam proses membuat atau menciptakan barang atau jasa yang diproduksi (output) perusahaan. Jadi, biaya adalah bebagai faktor (input) yang dikorbankan dengan tujuan untuk menghasilkan output dalam jumlah tertentu yang pada akhirnya dapat memperoleh profit (keuntungan yang lebih).

Biaya adalah beban yang harus ditanggung demi tersedianya suatu barang (produk) atau jasa yang siap untuk digunakan atau dikonsumsi oleh konsumen. ${ }^{10}$ Secara fundamental untuk menjelaskan konsep biaya merupakan suatu fungsi hubungan antara biaya produksi dengan tingkat output (keluaran) yang hendak dicapai dalam periode tertentu. ${ }^{11}$ Faktor-faktor produksi merupakan biaya aktual (berwujud) yang dapat dinilai dengan nominal uang sehingga total cost (total biaya) akan menggambarkan jumlah total faktor produksi yang telah dan akan dikorbankan. Penjelasan mengenai teori biaya (cost theory) menggunakan dua asumsi, (1) teori biaya pada perusahaan yang bergerak di bidang pasar persaingan sempurna. Output price (harga output) selalu ditentukan pada mekanisme pasar, (2) berbagai faktor produksi yang sedang dan

\footnotetext{
${ }^{11}$ Adiwarman A. K., "Ekonomi Mikro Islam" Cet7, Jakarta : Raja Grafindo Persada, 2015), 138.
} 
akan digunakan berupa barang serta modal tenaga kerja (SDM). ${ }^{12}$

Biaya dikelompokan menjadi tiga yaitu: biaya ekonomi, eksplisit, dan implisit. (1) Economic cost atau biaya ekonomi mengacu pada konsep bahwa sumberdaya memiliki penggunaan alternatif. Hasil pemanfaatan yang diasumsikan paling baik disebut opportunity cost (biaya oportunitas) yang menunjukan pengorbanan satu sumberdaya degan sumberdaya lain. (2) Biaya eksplisit merupakan biaya aktual atau berwujud yang dikorbankan perusahaan seperti pembayaran dengan uang tunai untuk memperoleh berbagai faktor produksi serta bahan baku yang dibutuhkan. (3) imputing cost (biaya implisit) merupakan biaya yang tidak berwujud seperti nilai waktu, tenaga, kesempatan atau peluang yang dikorbankan. ${ }^{13}$

Biaya ekonomi meliputi biaya eksplisit dan implisit yaitu biaya yang memang dikeluarkan dan diestimasi atas nilai sumber daya apabila digunakan untuk lainnya. Biaya eksplisit dapat dimisalkan sebagai pembayaran untuk pembelian bahan baku, upah pekerja, transportasi dan logistik, dan lain sebagainya. Jadi biaya eksplisit mencatat pembayaran aktual yang diberikan kepada para pemasok sumberdaya. Sementara itu,

\footnotetext{
${ }^{12}$ Masyhuri, "Ekonomi Mikro", ( Malang : UINMalang Press, 2007 ), 173.

${ }^{13} /$ bid, h. 102.
}

nilai atas waktu dan energi yang seharusnya diterima jika mengerjakan bisnis yang lain maka dinamakan biaya implisit. Dimisalkan terdapat seorang petani jeruk Garut memupuk kebunnya dengan menggunakan kotoran kambing yang diambil dari kandangnya sendiri. seharusnya ini dimasukan dalam biaya, akan tetapi kebanyakan orang (petani) tidak memasukannya. Dalam konsep produksi, biaya ekplisit dan implisit perlu dimasukan ke dalam struktur biaya tujuannya untuk memudahkan dalam perhitungan biaya. ${ }^{14}$

\section{Biaya Produksi}

Biaya produksi merupakan suatu beban biaya yang dikeluarkan perusahaan (input) baik secara eksplisit maupun implisit untuk menghasilkan output (barang dan jasa). Unsur-unsur biaya produki yaitu biaya pembelian berbagai bahan baku (bahan dasar) termasuk bahan setengah jadi, bahan complement (pembantu/pelengkap), balas jasa tenaga kerja (tenaga kerja paling bawah hingga paling tinggi), biaya penyusutan pada peralatan produksi, modal, biaya penungjang lainnya (biaya asuransi, biaya angkut, biaya keamanan, biaya administrasi, biaya listrik, dan biaya pemeliharaan), biaya

${ }^{14}$ Arif H., “Ekonomi Mikro Islam" : 'Pendekatan Intergratif', ( Malang : UB. Press, 2018 ), 203. 
pemasaran (biaya iklan dan sejenisnya), biaya pajak, serta biaya-biaya lainnya.

Biaya produksi yang telah dikorbankan oleh perusahaan tentunya bisa dibedakan menjadi fix cost (biaya yang selalu tetap) dan variable cost (biaya yang selalu berubah). Total cost merupakan biaya yang ditotalkan secara keseluruhan. Jadi dalam biaya produksi akan mencakup tiga aspek biaya saja, total cost (biaya total), total fixed cost (biaya tetap total), total variable cost (biaya berubah total). Biaya Jangka pendek

Biaya jangka pendek merupakan perubahan kuantitas input (biaya) yang digunakan produsen pada periode tertentu seperti biaya harian, mingguan, bulanan dan lain sebagainya. ${ }^{15}$ Biaya jangka pendek terdiri atas :

\section{Total Fixed Cost}

TFC merupakan total biaya yang tidak dapat dipengaruhi oleh maksimal atau minimalnya total kuantitas produksi yang dikorbankan, bahkan jika produsen bermaksud menghentikan sementara kegiatan

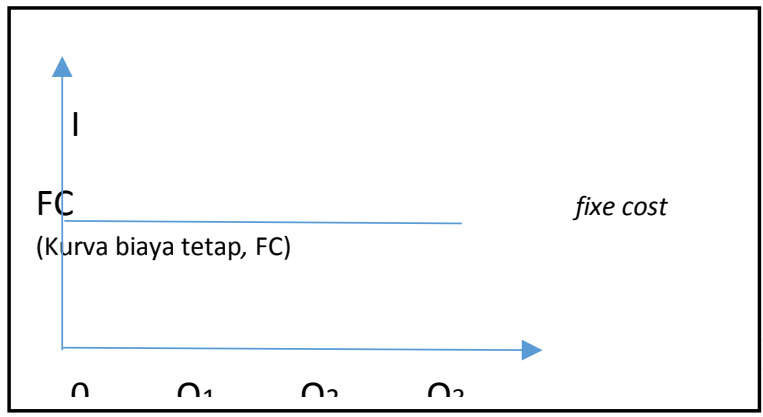

produksi. ${ }^{16}$ total fixed cost adalah seluruh biaya yang wajib dikeluarkan produsen yang ditujukan untuk memperoleh faktorfaktor produk yang tidak dapat dirubah jumlahnya (fix), seperti biaya membayar gaji pegawai, membeli peralatan produksi berupa mesin, membayar pajak, membayar zakat, membayar bunga, menyewa gedung atau mendirikan gedung.

\section{Total Variable Cost}

TVC merupakan kebalikan dari biaya tetap, biaya variable adalah total biaya yang yang wajib dikeluarkan produsen yang dapat dirubah kuantitasnya sesuai dengan target produksi. apabila dilustrasikan jika produsen menghendaki untuk meningkatkan total output, maka total biaya variabel yang dibutuhkan juga meningkat. ${ }^{17}$ Biaya variabel seperti biaya pembelian bahan baku dan biaya-biaya sejenisya.

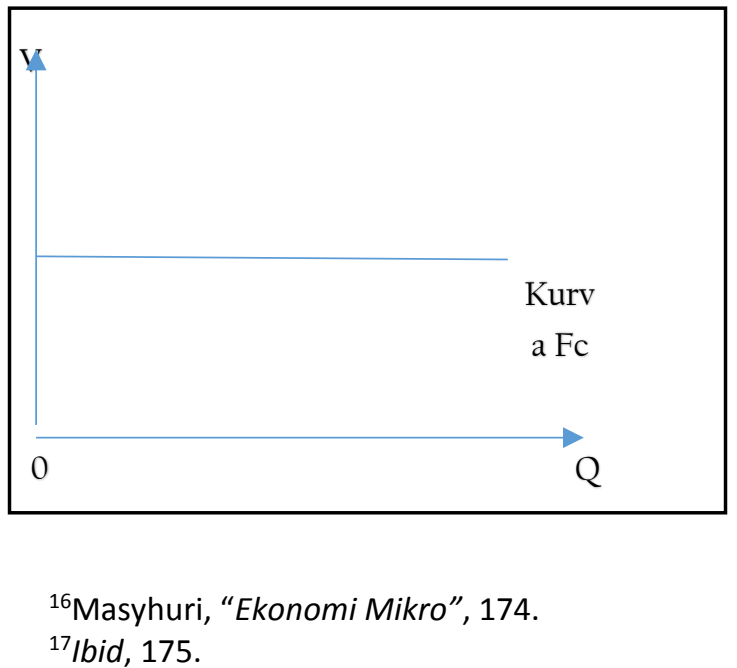


Total Cost

TC merupakan biaya yang besarannya diperoleh dari hasil penjumlahan total fixed cost (biaya tetap total) dan total variable cost (biaya variabel total). ${ }^{18}$ Biaya total adalah biaya yang harus dikeluarkan oleh produsen sebagai akibat dari kegiatan prosuksi dalam menghasilkan output dimana besaran biaya total tersebut diperoleh dari penjumlahan antara biaya tetap dan biaya variabel. Semakin besar biaya tetap dan biaya variabel yang dikeluarkan oleh perusahaan maka akan berpengaruh pada besaran biaya total (total cost).

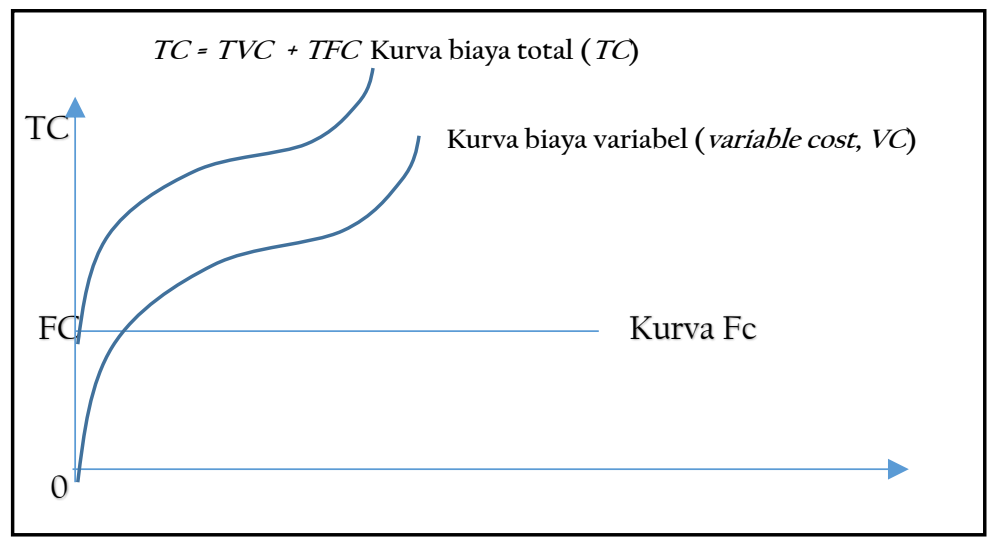

Marginal Cost

MC merupakan rumus persamaan biaya adalam kegiatan produksi yang besarannya dapat diperoleh dari pembagian rata biya total terhadap output yang dihasilkan. Fungsi rumus persamaan biaya marginal untuk mengetahui perubahan biaya total apabila total output berubah satu unit. ${ }^{19}$

$$
\mathrm{MC}=\Delta \mathrm{C} / \Delta \mathrm{Q}
$$

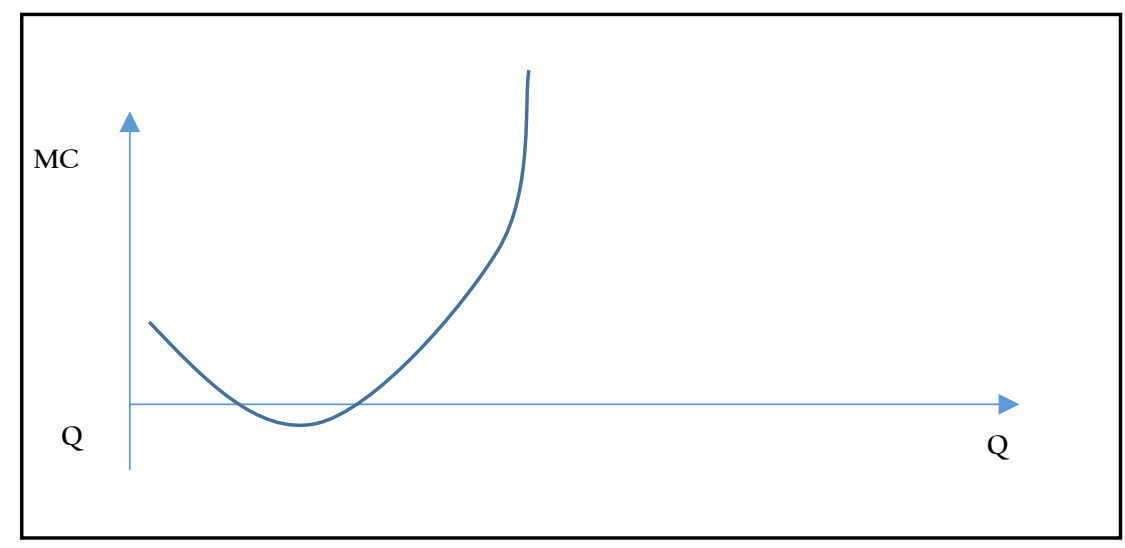

${ }^{18}$ Suryawati, "Teori Ekonomi Mikro", 83.

${ }^{19}$ Sri A. dan Y.B Kadarusman, "Teori Ekonomi Mikro", ( Yogyakarta, BPFE, 2008 ), 41. 
Average Fixed Cost

AFC merupakan rumus persamaan metode membebankan biaya tetap pada matematis yang fungsinya untuk output perunitnya.

$$
A F C=T F C / Q
$$

Average Fixed Cost

AFC merupakan rumus persamaan matematis yang fungsinya untuk mengetahui ratarata biaya tetap, dengan metode membebankan biaya tetap pada output perunitnya.

$$
A F C=\boldsymbol{T F C} / Q
$$

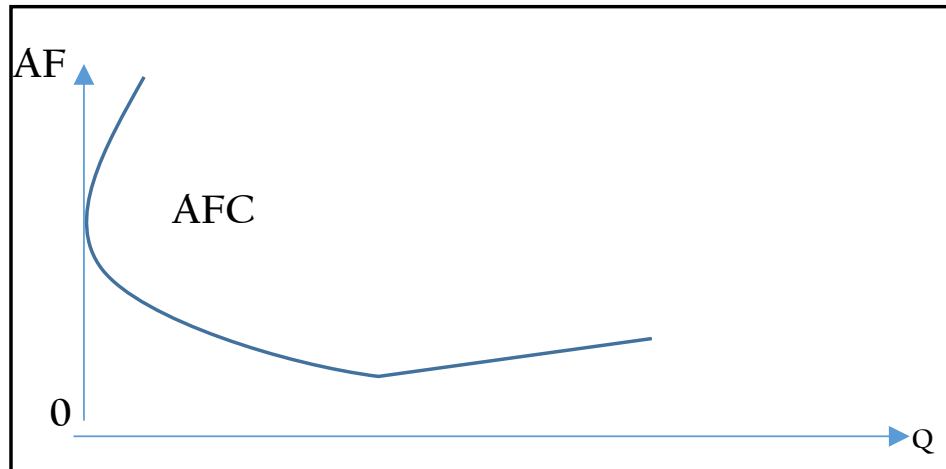


Average Variable Cost

AVC merupakan rumus persamaan matematis yang fungsinya untu mengetahui rata-rata biaya tetap, dengan metode membebankan biaya variabel pada output yang dihasilkan setiap unitnya.

\section{$A V C=T V C / Q$}

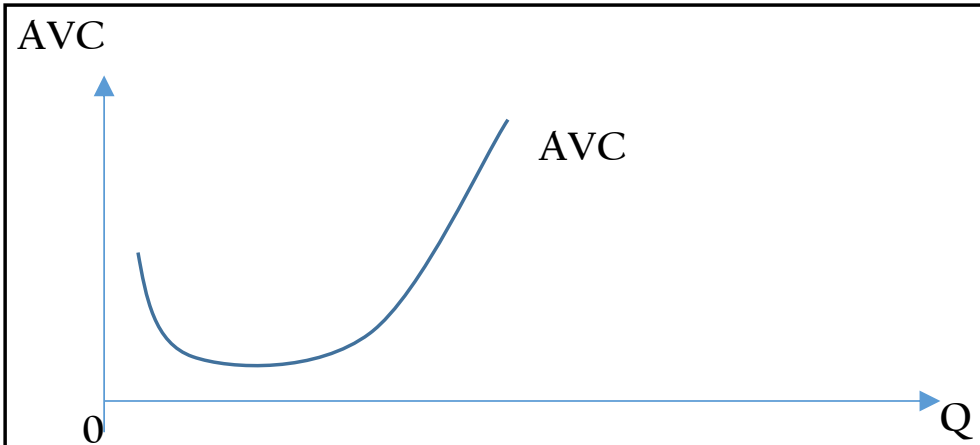

Average Cost ${ }^{20}$

AC merupakan besaran biaya rata-rata yang diperoleh dari hasil pembagian total biaya produksi terhadap seluruh ouput yang diperoleh.

$$
A C=T C / Q
$$

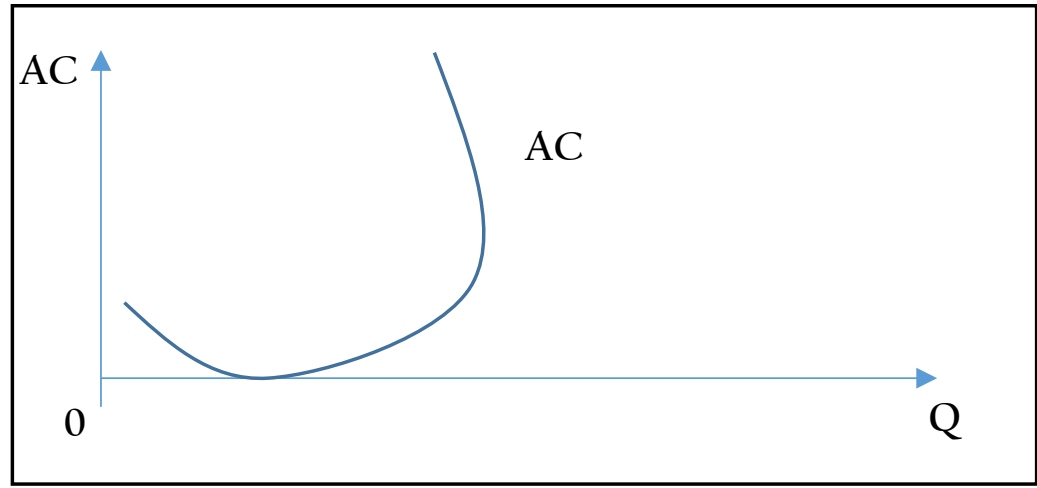

${ }^{20} \mathrm{https} / / /$ www.academia.edu, diakses pada tanggal 24 Maret 2021. 


\section{Biaya Jangka Panjang}

Biaya jangka panjang merupakan berbagai biaya yang dikeluarkan produsen yang dapat dirubah besarannya termasuk dalam hal ini biaya tetap. ${ }^{21}$ Biaya jangka panjang ini memungkinkan setiap produsen untuk menguba semua jenis biaya, biaya

Perbandingan Implementasi antara Sistem Bunga dan Sistem Bagi Hasil pada Biaya

Pembayaran bunga yang harus dikeluarkan oleh produsen sifatnya flat (tetap). ${ }^{22}$ Perusahaan harus membayar beban bunga disetiap bulannya. Besaran pembayaran bunga tersebut tidak dipengaruhi oleh kondisi perushaan, baik perusahaan dalam kondisi untung maupun dalam kondisi rugi. Sehingga beban bunga yang dibayarkan perusahaan menjadi bagian dari biaya tetap yang dirubah mencakup biaya tetap dan biaya variabel. Produsen dalam biaya jangka panjang ini dapat menambah ataupun mengurangi penggunaan faktor produksi, dengan tujuan akhir produsen dapat lebih mengefektif dan mengefisienkan biaya dalam kegiatan produksi.

(fixed). Begitupun dengan menjadikan biaya bunga sebagai biaya tetap secara otomatis akan meningkatkan biaya total (total cost).

Seorang pengusaha meminjam sejumlah uang di lembaga keuangan yang menerapkan sistem bunga. Nominal uang yang dipinjam Rp 45,000,000,- bunga yang ditetapkan sebesar $1 \%$ pertahun. Hasil kalkulasi biaya bunga yang sifatnya tetap tersebut adalah 450,000,- maka besaran biaya tersebut akan dimasukan pada biaya tetap sebesar 4,200,000,- per bulannya.

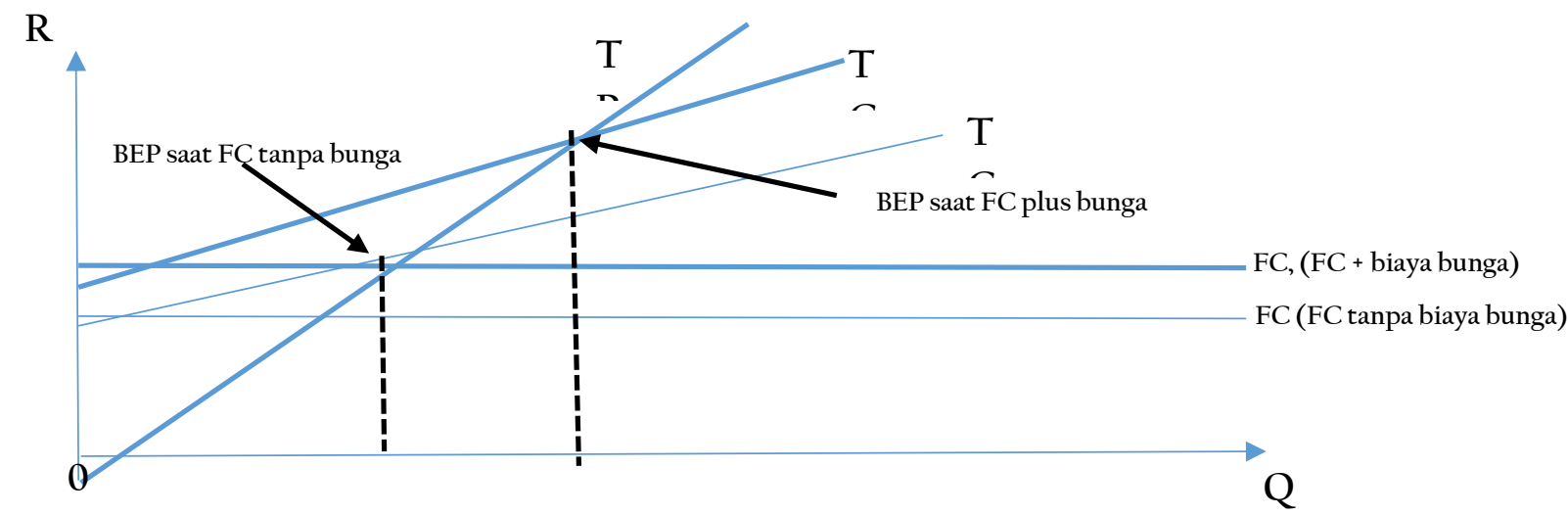

${ }^{21}$ Suryawati, “Teori Ekonomi Mikro", 89.

${ }^{22}$ Adiwarman A. K., Ekonomi Mikro Islam, 139. 
Sistem bagi hasil tentu berbeda dengan dengan sistem bunga, sistem bagi hasil akan berpengaruh pada total pendapatan (total revenue/TR). Seorang petani yang melakukan kerja sama dengan pihak pemilik modal, kesepakan diperoleh bahwa prosentase (nisbah) bagi hasil 60:40, pihak pertama bertindak sebagai pemilik dana (shahibul mal) sedangkan petani bertindak sebagai pengelola dana (mudharib). Jika diketahui harga 1 karung beras Rp. 100.000,- revenue yang diterima shahibul mal Rp. 60,000,sedangkan petani sebagai pengelola dana (mudharib) memperoleh revenue Rp. 40,000,bila terjual 2 karung beras maka Rp 80,000,dan begitu seterusnya.

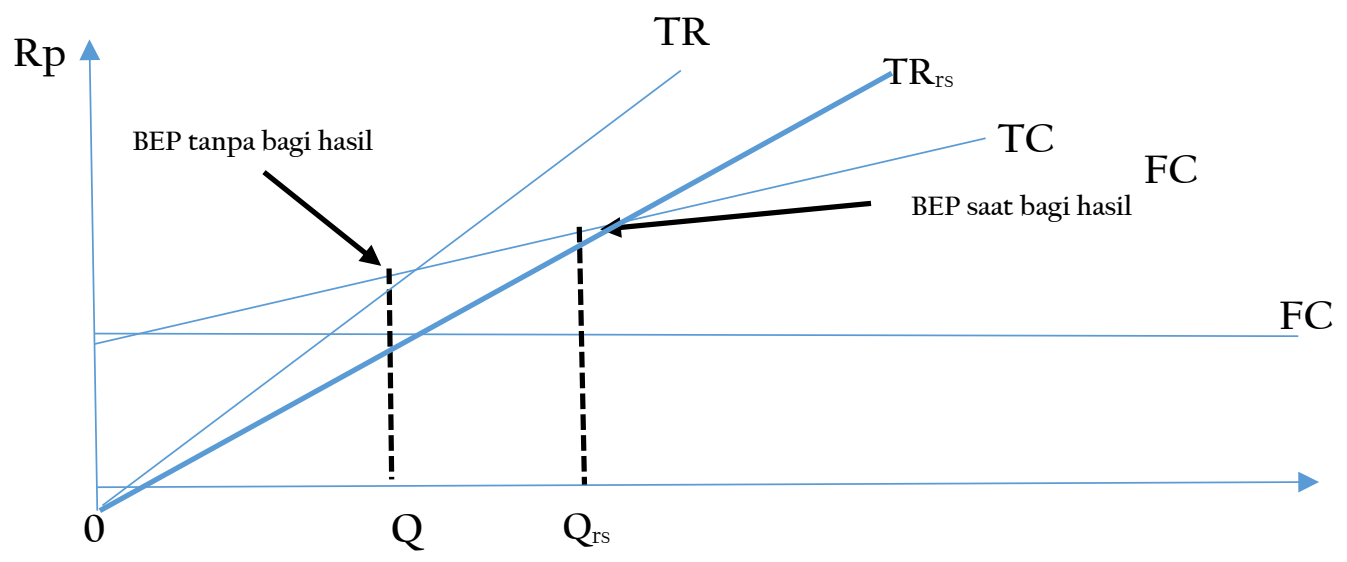

Perbandingan antara Keuntungan Dibagi (Profit Sharing) dan Pendapatan Dibagi (Revenue Sharing)

Mudharabah merupakan suatu akad muamalah yang diperbolehkan dalam syariah islam, implementasi akad mudharabah ini dapat menerapkan dua sistem bagi hasil yaitu Profit dan Revenue Sharing, merupakan akad kerjasama dalam bisnis antara shahibul mall (pemilik dana) dengan mudharib (pengelola dana). ${ }^{23}$ Akad mudharabah bisa sah apabila sudah terdapat kesepatan dalam pembagian nisbah bagi hasil antara shahibul mall (pemilik dana) dengan mudharib (pengelola dana), kemudian apabila terjadi kerugian dalam kegiatan usaha tersebut maka kerugian akan menjadi beban bagi pemilik dana selagi kerugian tersebut terjadi bukan diakibatkan oleh kelalaian pengelola dana usaha.

Mereka yaitu shahibul mall (pemilik dana) dan mudharib (pengelola dana) membuat kesepakatan tentang biaya. Jika kesepakatannya biaya menjadi tanggungan pelaksana (pengelola dana), maka sistem yang digunakan dalam mekanisme bagi

23/bid, 142. 
hasil adalah revenue sharing (bagi peneri- (shahibul mall), maka sistem yang digunakan maan/pendapatan), sebaliknya jika kesepakatannya biaya menjadi beban pemiliki dana sharing (bagi keuntungan).

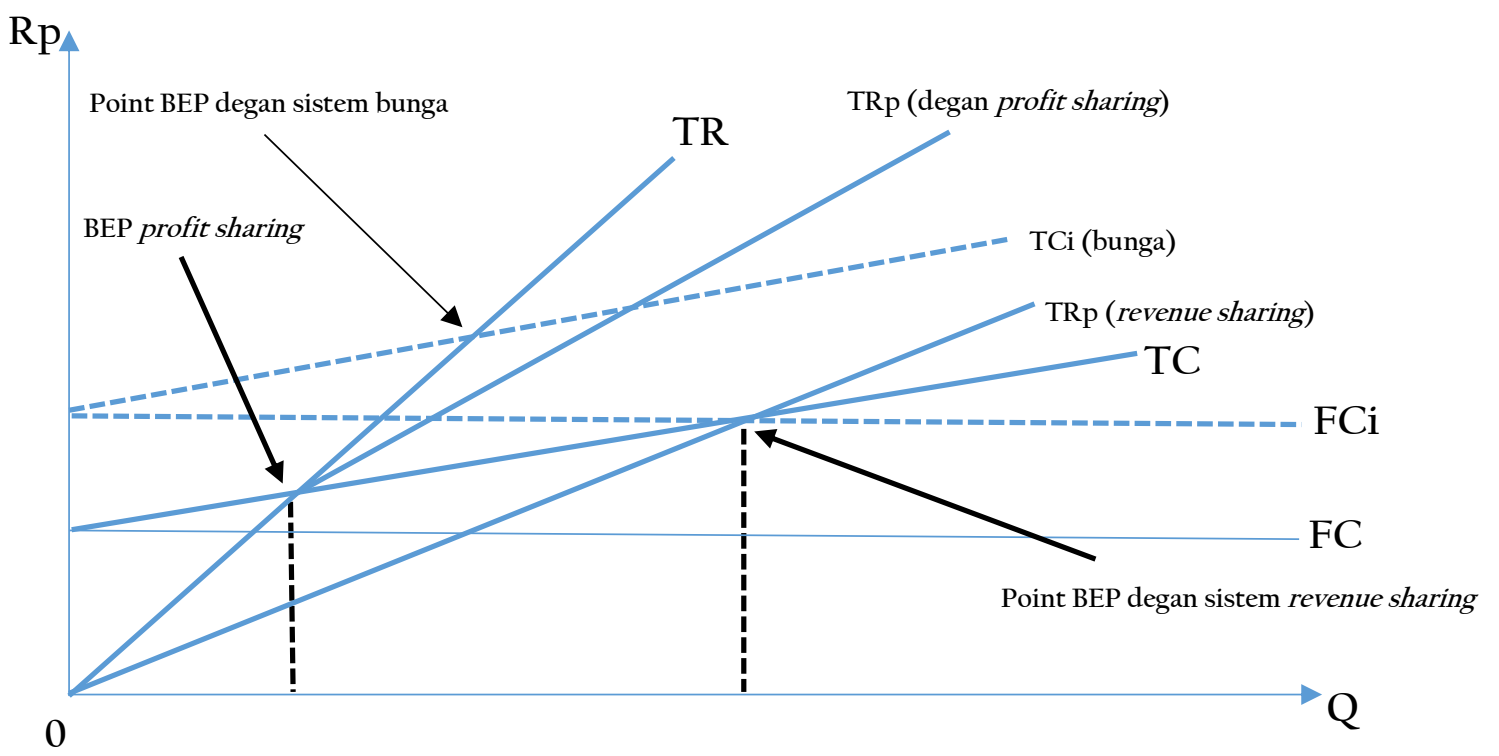

Pergeseran kurva TR (total revenue) menjelaskan perbedaan mekanisme bagi hasil antara revenue sharing (bagi penerimaan/pendapatan) dengan profit sharing (bagi keuntungan), pada sistem bagi penerimaan/pendapatan (revenue sharing) kurva TR berputar dan bergeser mendekati garis horizontal.

Minimalisasi Biaya dengan Asumsi Q Sama

Meminimalisir biaya produksi dengan harapan dapat mengefisienkan biaya produksi. Metode yang digunakan adalah membandingkan dua sistem biaya yang mempengaruhi total biaya (total cost). Kedua sistem tersebut yaitu biaya dengan sistem bagi hasil dan biaya dengan sistem bunga. Total biaya apabila diperoleh dengan menggunakan sistem bunga akan meningkat lebih tinggi, hal ini karenakan biaya bunga masuk pada biaya tetap (fix cost). Berbeda halnya dengan total biaya yang diperoleh dengan sistem bagi hasil, dimana biaya dengan sistem bagi hasil tersebut tidak akan berpengaruh terhadap biaya total (total cost). Korva berikut ini menggambarkan TC sebagai total biaya dengan sistem bagi hasil, sedangkan $\mathrm{TC}_{\mathrm{i}}$ sebagai total biaya dengan sistem bunga. ${ }^{24}$

\footnotetext{
${ }^{24}$ Ibid, 145.
} 


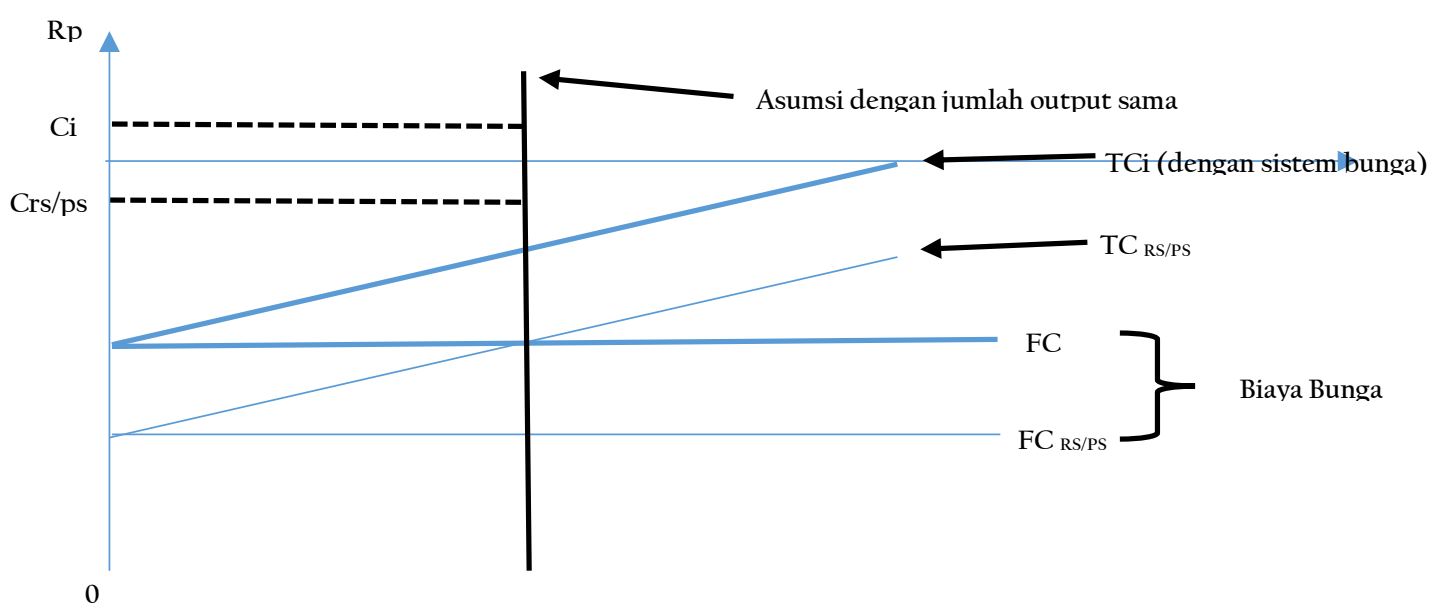

Sumbu X merupakan gambaran tingkat produksi dengan Q sama. Dibuat suatu garis vertikal yang memotong TC dan TCi. Dibuat suatu garis horizontal di sumbu Y yang saling berpotongan dengan garis vertikal pada TCrs/ ps dan TCi. Maka dapat disimpulkan tingkat produksi dengan asumsi $\mathrm{Q}$ sama, biaya total dengan menerapkan sistem bagi hasil TC rs/ ps terbukti lebih rendah atau kecil dibandingkan dengan biaya total pada TCi. Sesuai asumsi awal keberadaan bunga menjadi beban biaya tetap (fix cost) yang berakibat pada meningkatnya biaya total.

Maksimalisasi produksi dengan asumsi biaya tetap (tidak ada perubahan biaya)

Memaksimalkan output dalam kegiatan produksi dengan tidak merubah input atau biaya yang dikeluarkan (optimalisasi produksi).25 Disajikan sebuah kurva yang menggabarkan perbadingan total biaya sistem bunga dengan total biaya dengan sistem bagi hasil. Hasil analisis kurva dibawah ini, dengan asumsi bahwa total biaya yang dikeluarkan jumlahnya sama. Tujuan dari perbandingan pada kurva tersebut adalah untuk mengetahui seberapa efektif dan efisienkah penggunaan sistem bunga atau sistem bagi hasil pada kegiatan produksi dengan harapan output yang dihasilkan, akan tetap biaya yang dikeluarkan tetap. Fakta menunjukan dengan penggunaan sistem bagi hasil terbukti dapat meningkatkan output.

${ }^{25}$ Ibid, 146. 


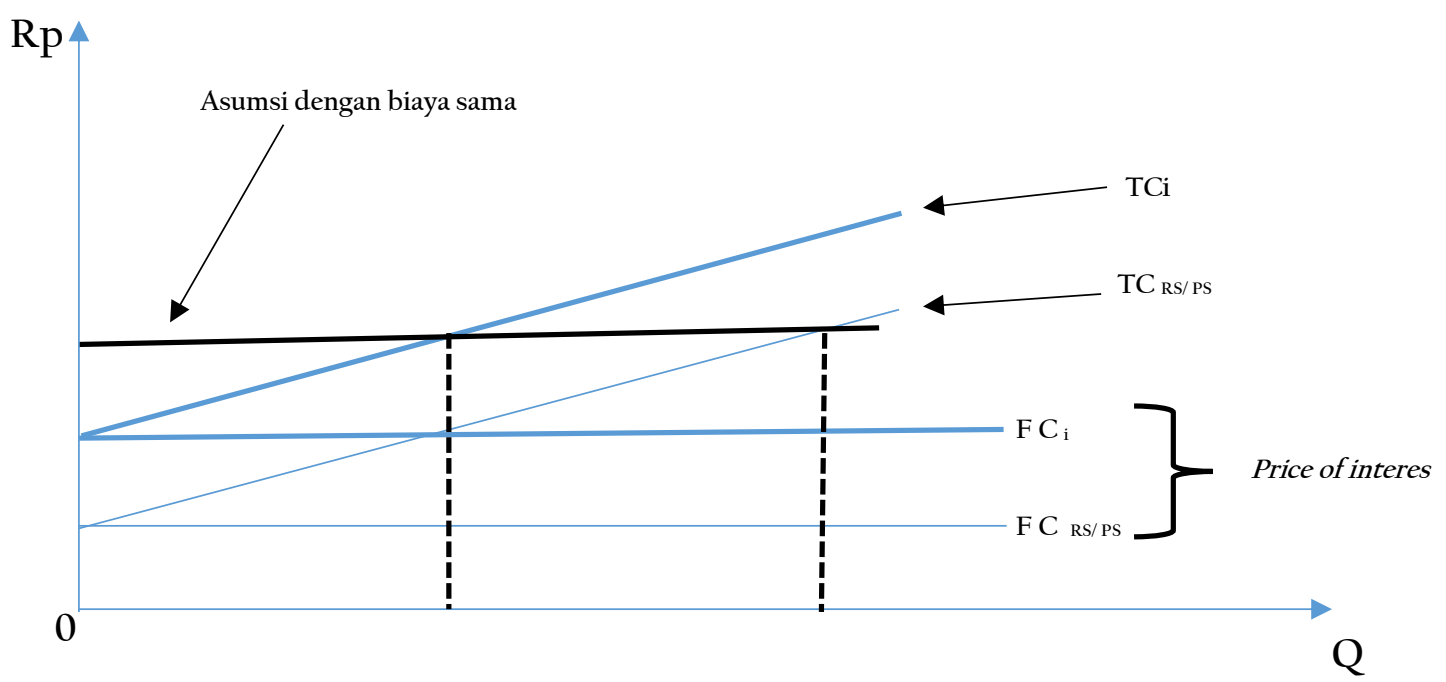

Y merupakan sumbu yang menunjukan total biaya produksi (TC) yang diasumsikan sama baik dengan sistem bagi hasil maupun sistem bunga. Dibuat suatu garis horizontal yang memotong TC serta TCi pada sumbu Y. dibuat garis vertikal yang mengarah ke sumbu $X$ yang saling berpotongan dengan garis horizontal TC dan TCi. Faktanya dengan biaya total yang sama (TC), kuantitas output sistem bagi hasil yang ditunjukan Qrs/ ps berada pada posisi lebih besar jika dibandingkan dengan kuantitas output dengan sistem bunga Qi yang ditunjukan Qrs/ ps > Qi. Hal ini membuktikan bahwa kegiatan produksi dengan perolehan modal dari sistem bagi hasil lebih efektif dan efisien.

\section{SIMPULAN}

Kesimpulan dalam pembahasan pada tulis artikel sederhana ini mengenai perbandingan sistem bagi hasil dan bunga serta implementasi pada biaya. Terdapat empat aspek dalam perbandingan sistem bagi hasil dan bunga serta implementasinya pada biaya, diantarana sebagai berikut:

Biaya bunga yang harus dibayarkan produsen bersifat tetap, sehingga termasuk pada biaya (fixed cost), sedangkan dalam sistem bagi hasil akan mempengaruhi pada total revenue.

Sistem profit sharing, ketika rugi kurva total revenue digambarkan dengan mulut buaya bawah, sedangkan ketika untung digambarkan dengan mulut buaya atas, berbeda halnya dengan sistem revenue sharing, kurva total revenue bergeser mendekati garis horizontal.

Produksi dalam jumlah yang sama (Q), biaya total sistem bagi hasil selalu lebih kecil dibandingkan sistem bunga, dikarenakan bunga menjadi beban bagi produsen, karena 
biaya tetap naik, maka akan meningkatkan biaya total.

Memaksimalkan produksi tanpa ada perubahan biaya, dengan menggunakan kurva TC yaitu membandingkan biaya total sistem bunga dengan sistem bagi hasil, fakta menunjukan bahwa hasil analisis kurva TC menunjukkan biaya yang sama, jumlah produksi yang dihasilkan sistem bagi hasil lebih efisien dan efektif bila dibandingkan dengan sistem bunga.

\section{DAFTAR PUSTAKA}

Adiningsih, S. dan Y.B Kadarusman. “Teori Ekonomi Mikro". Yogyakarta : BPFE, 2008.

Antonio, M. S. “Bank Syariah”: Dari Teori ke Praktik. Jakarta : Gema Insani, 2001.

Bachrudin S. dkk. "Ekonomi Mikro". Yogyakarta : Budi Utama, 2019.

Hoetoro, Arif. “Ekonomi Mikro Islam” : Pendekatan Intergratif. Malang : UB Press, 2018.

Karim, Adiwarman A. “Ekonomi Mikro Islam” : Cet-7. Jakarta : Raja Grafindo Persada, 2015.

Muhamad. "Sistem dan Prosedur Operasional Bank Syariah". Yogyakarta : UII Press, 2005.

Muhamad dan Dwi S. "Akuntansi Perbankan Syariah". Yogyakarta : Trust Media, 2009.

Masyhuri. "Ekonomi Mikro". Malang : UIN Press, 2007.

Saeed, A. "Bank Islam dan Bunga". Yogyakarta : Pustaka Pelajar, 2004.

Suryawati. "Teori Ekonomi Mikro". Yogyakarta : YKPN, 2010.

https://www.academia.edu. dikutip : Minggu, 4 Oktober 2015, 11:00). Diakses pada tanggal 24 Maret 2021. 